\title{
La fogata del forastero
}

\author{
Esther C. Segura Ceciliano ${ }^{1}$ \\ 26/02/2015
}

Dicen las malas lenguas que por las bajuras del Valle, allá -al otro lado de las colinas- se escuchan en las noches veraniegas los gritos y silbidos de un jinete sin domar, azuzando a su bestia y seguido por su can. Tanto había escuchado la historia del mencionado jinete que, un día le pregunté a mi madre qué sabía de él y jvaya que sí sabía la mujer! Ella se llama a sí misma víctima del hombre que dejó la casa buscando aires nuevos, de los que olían a libertad.

Lo que cuentan es que hace muchos años el hijo de un soldado de la revolución se le reveló al tata y se largó de la hacienda. Leonardito, lo llamaban por lo dócil que parecía ser. La familia era como lo que llaman acomodada, pero el hijo se zafó de las obligaciones que como heredero tenía que contraer a la muerte del padre y se fue a correr mundo.

Según cuentan por ahí, el susodicho era un pobrecito soñador y medio bohemio. Siempre andaba pegado a una guitarrilla vieja que cuidaba con gran esmero y se pegaba sus tonadas cuando creía que nadie lo escuchaba. Y por eso mismo le volaban juete; por ser tan mariposita, como solía llamarlo el tata. Lo que más se dan taco en contar cuando hablan de él, es de la boda que se celebraba en el pueblo la mañana que se marchó y de la novia que dejó vestida y alborotada. ¡Y ni qué decir de la familia, con la dote que estaban perdiendo por los caprichos de un jovenzuelo dizque rebelde!

Tenía los dieciséis años recién cumplidos.

No pasó ni un día, cuando ya el viejo soldado había firmado un nuevo testamento, en el que no le dejaba al muchacho ni una cabeza de ganado... ni una peseta partida a la mitad. Tanto fue el desaire para el viejo, con su único hijo varón yéndose a perder y un par de hijas poco agraciadas -pero medio mojigatas, cabe decir- que, al cabo de un mes ya su señora esposa le rezaba los nueve días. Aquello parecía más la fiesta de la Candelaria que un rezo de muerto; con todas las caras reconocidas de la política y los negocios del valle, que hasta el alcalde se dejó caer por ahí, para darse su taquito de chicharrones y aguardiente después de los nueve rosarios.

Pero así las cosas, nadie logró dar con el rastro del muchacho. Muchos ya lo daban por muerto, alegando el suceso a las artes de alguna bicha cascabel o a las garras de un león de montaña.

Dicen que ya lo tenía todo preparado, que desde hacía días venía alistando las alforjas y la lona; hasta una capa de manta y todo lo escondió entre unos matorrales. Y el caballo ensillado que, fue el mismo en el que cabalgó hasta las puertas de la iglesia.

¿Qué cómo sé eso? Es que la chiquilla de la cocinera de la casa grande, vino a contar años después que fue ella la que le alistó las alforjas a cambio de unas manoseadas en el establo. ¡La muy poca pena! Mas siempre afirmó no saber para donde se iba su patroncito. La cosa es que, una vez ido, jamás vuelto.

Muchos dicen que también han visto de lejos como chispas de luz en las laderas de las montañas, las que rodean el ancho valle; $y$ en las orillas de los caminos por donde ya no pasa nadie. Han dicho que se les parece como a fuegos encendidos. Pero nunca han encontrado las cenizas ni las pisadas de sus zapatos ni tampoco las huellas de su cimarrón, cuando por la mañana recorrían el lugar donde

\footnotetext{
${ }^{1}$ Estudiante de la Carrera Enseñanza del Castellano y la Literatura. Universidad de Costa Rica, Sede de Occidente. Correo electrónico: esthersegura18@gmail.com
} 
creían haberlo visto. Como cosa de malas artes, se atrevían a afirmar. Y de repente, la gente comenzaba a santiguarse al mirar hacia allí.

La parte que no saben contar es sobre las razones que un muchachito así podía tener para irse tan a la carrera, como huyendo de la buena vida que pintaba tendría si se casaba con la muchacha que dejó plantada.

Cuando mi mama lo recibió en la posada de mi abuelo, el forastero estaba hecho una lástima; quizás llevaba una semana sin comer y estaba ensangrentado: una herida infectada en su pierna derecha. Su caballo apenas lo aguantaba. Cuenta también, que el hombre no podía ni hablar. Cayó al suelo, desmayado. Tardó un par de días en despertarse. Pero aún entonces, no pudo tragar la sopa de verduras que le dieron para comer. El pobrecillo seguía muy mal. Habían llamado a un doctor, para que le viera la pierna, pero éste no hizo gran cosa: unos ungüentos y ya. La curandera fue la que le preparó unos mejunjes mejores que hicieron que se le bajara la hinchazón y se le fuera cerrando la herida hasta que quedó cicatrizada. Después de eso, pasaron como dos semanas para el muchacho pudiera sentarse en la cama. Y así, poco a poquito fue recuperándose. Y así poco a poquito, a mi mama fue calentándosele el comal en el fogón.

Resulta que mi abuelo dispuso que -de las seis hermanas de mi mama- fuera ella la que cuidara al forastero. El pobre viejillo andaba tan machacado por las dolencias del espinazo, que no se dio cuenta de las tortillas que se cocinaban al fuego: pañitos de agua fría de más, sopitas de verduras y carne que mi madre le brindaba al extraño, y las salidas a hurtadillas por las noches desde el cuarto de las siete muchachas hasta la troja donde estaba el catre que dispusieron para el muchacho enfermo y otros más para cuando llegaran viajeros.

Al cabo de unas semanas, cuando se hubo recuperado del todo $y$, pudo hablar y moverse, las dichas ollitas de carne y pañitos de agua fría, se convirtieron en palabras bonitas, roces intencionados y manoseos pasados de tono. Días después, el muchacho se ofreció ayudarles en lo que necesitasen, según dijo, para poder pagarles de alguna forma el mantenerlo vivo.
Las siete muchachas estaban paradas al lado de la matrona, escuchando embebidas cada palabra del mozo que tenían enfrente. No se parecía en nada al débil y maltrecho muchachillo que llegó a su posada. La madre ya estaba maquinando una boda con alguna de sus hijas casaderas, sin imaginarse siquiera el pasado que pudiera tener semejante hombre.

Lo puso a arreglar el patio, a sembrar en la milpa y en la huerta, a ordeñar las cuatro vacas y pasarlas de un pastizal a otro junto con los terneritos, y cuanta cosa fuera, con tal de no dejarlo marcharse. Pero es que ella tampoco olía las tortillas quemadas, a pesar de ser tan sabida en esas cosas de la vida. Un mes después, más o menos, según cuenta mi mama, se vinieron a dar cuenta de la metida de patas de la más niña de las siete, cuando aparecieron los mareos y las salidas mañaneras al monte.

Mama dice que cuando se lo dijo al muchacho ¡puso una cara de espanto! Como si hubiera visto al patas en persona. Pero de inmediato se recompuso como pudo, la agarró y la sentó en su regazo, como habría hecho muchas otras veces y le dijo al oído algo que jamás olvidaría: le propuso marcharse con él. Y que fuera esa misma noche.

¡Pero qué va! Esa no era la vida que una muchachita como ella debía tener. Mis abuelos la criaron para el hogar, como todas las mujeres. Le enseñaron que tenía que casarse y criar a los hijos, no a meterse con cualquier juan vainas que le pasara en las narices. Sin embargo, ya ven cómo cambia la cosa cuando a una le pintan el mundo con rosas y mariposas. Se equivocó al pensar un hombre nacido para conocer mundo se quedaría con ella y formarían un hogar porque tendrían una cría. Ella creyó que él no se iría esa noche. Creyó que no se iría nunca. Pero nada lo detuvo.

Ensilló su caballo Adenio y -seguido por su fiel amigo Rozbel, el can- se fue de allí llevándose consigo los cuatro tiliches con que llegó un par de meses atrás; y dejando más penas que alegrías, otra vez.

Yo no creo que Leonardo fuera un cobarde por irse tan a la carrera de nuevo. No creo que estuviera escapando de nada, creo que quería ser libre por la 
simpleza de serlo cabalgando y durmiendo al aire libre, cobijándose con las estrellas, cantándole con su guitarra a la luna y calentándose con una fogata. A veces imagino que volverá a la posada como un hombre hecho y derecho. Sin arrepentimientos. Sé que él nunca ha sido un cobarde. El muchacho que era en aquellos días, no estaba listo para meterse a vivir en un hogar. Gracias a Dios que se fue de la casa de sus padres y luego también de la posada. Necesitaba sentirse salvaje. Gracias a Dios que nada lo detuvo de serlo.

Leonardo no podría ser un cobarde. Solo un hombre de verdad tendría el valor necesario para sobrevivir y conquistar las montañas y los valles cada noche, a su paso. Puede que no haya visto su fogata, o que nunca escuche los relinchos de su bestia, pero sé que anda por ahí. Ninguna culebra ni bestia de monte podría ganar batalla contra un muchacho como lo era Leonardo.

Tan simple como eso. Lo que cuenten las malas lenguas... esos son otros cien pesos. 